\title{
Oil Wettability and Sliding Properties of Organic and Inorganic Hybrid Coating Films Prepared from Methyltriethoxysilane and Various Metal Alkoxides
}

\author{
Manabu FUKUSHIMA, Eiichi YASUDA, ${ }^{*}$ Hideki KITA, Hideki HYUGA, Kazuo OSUMI, ${ }^{* *}$ \\ Hayato KAWABATA, ${ }^{*}$ Yasuto HOSHIKAWA* and Yasuhiro TANABE* \\ National Institute of Advanced Industrial Science and Technology (AIST), 2266-98, Shimo-Shidami, Moriyama-ku, Nagoya-shi 463-8560 \\ *Materials \& Structures Laboratory, Tokyo Institute of Technology, 4259, Nagatsuta, Midori-ku, Yokohama-shi 226-8503 \\ **Isuzu Advanced Engineering Center Ltd., 8, Tsuchidana, Fujisawa-shi, Kanagawa 252-8501
}

\section{メチルトリェトキシシランと種々の金属アルコキシドから作製した有機無機ハイブリッド コーティング膜のオイルへの塗れ性と摺動特性}

\author{
福島 学·安田榮一* . 北 英紀 ·日向秀樹 · 大角和生 ${ }^{* *}$. 川端隼仁*.干川康人*. 田邊靖博* \\ (独)産業技術総合研究所先進製造プロセス研究部門，463-8560 名古屋市守山区下志段味穴ヶ洞 2266-98 \\ *東京工業大学応用セラミックス研究所, 226-8503 横浜市緑区長津田町 4259 \\ **(株)いすが中央研究所, 252-8501 神奈川県藤沢市土棚 8
}

\begin{abstract}
The oil wettability and sliding property of polymethylsilsesquioxane (PMSQ) based organic inorganic hybrid coating films prepared from methyltriethoxysilane and various metal alkoxide were investigated. The wettability of oil increased in the order of PMSQ $<$ Ta- $<$ Ti- $<$ Al-PMSQ, and was strongly affected by the surface roughness. The friction coefficient showed that Ti-PMSQ among hybrid coating films was the lowest value, which was found to be due to the presence and maintenance of the lubricating oil film during the sliding tests.
\end{abstract}

[Received January 31, 2006; Accepted April 19, 2006]

Key-words : Wettability, Sliding property, Polymethylsilsesquioxane, Organic inorganic hybrid, Coating film

\section{Introduction}

Polymethylsilsesquioxane (PMSQ) hybrid materials have recently been gathering significant interest for their application in coating films because of their excellent optical, protective, anti-corrosion, hydrophilic, and insulation properties. ${ }^{1)-3)}$ This hybrid comprises $T^{1}, T^{2}$, and $T^{3}$ unit structures, where $T^{n}$ is shown as the siloxane unit structure of $\mathrm{CH}_{3} \mathrm{Si}$ $(\mathrm{OSi})_{n} X_{3-n}[n=1-3$ and $X=\mathrm{OR}$ or $\mathrm{OH}, \mathrm{R}=$ alkyl group $]$. Metal alkoxide is often used with the precursor silicon alkoxide and copolymerized, as metal alkoxide can play a catalytic role in the hydrolysis-condensation of silicon alkoxide. ${ }^{4)}$

Recently, the sliding properties of PMSQ hybrid materials have also been investigated. Earlier authors have reported on the wettability and sliding properties of PMSQ bulk material..$^{5)}$ However, the sliding properties of coating film and the effect on wettability and sliding properties of the addition of metal alkoxide have not been investigated sufficiently. In particular, regarding oil wettability, Kita et al. reported on several important factors for decreasing the friction coefficient under lubrication. $\left.{ }^{6)}, 7\right)$

In this study, we briefly report on the relationship between oil wettability, sliding properties, and the metal component in PMSQ coating films.

\section{Experimental}

$\mathrm{CH}_{3} \mathrm{Si}\left(\mathrm{OC}_{2} \mathrm{H}_{5}\right)_{3}$ methyltriethoxysilane (MTES) was used as precursor silicon alkoxide (Shin-Etsu Chemical Co., Ltd., Tokyo). Various metal alkoxides of $\mathrm{Ta}\left(\mathrm{OC}_{2} \mathrm{H}_{5}\right)_{5}, \mathrm{Ti}(\mathrm{OCH}$ $\left.\left(\mathrm{CH}_{3}\right)_{2}\right)_{4}$ (High Purity Chemical Laboratory Co., Ltd., Saitama) and $\mathrm{Al}\left(\mathrm{O}\left(\mathrm{CH}_{3}\right) \mathrm{CHC}_{2} \mathrm{H}_{5}\right)_{3}$ (Kanto Chemical Co., Inc., Tokyo) were used as metal component sources. For stabilizing these metal alkoxides against moisture, acetylacetone (AcAc) was used, which can result in the formation of a chelate complex with metal alkoxide. The mixture of metal alkoxide $/ \mathrm{AcAc}=1 / 2$ in a molar ratio was stirred for $1 \mathrm{~h}$. These operations were carried out in a glove box under flowing dry Ar gas.

The mixture of metal alkoxide with AcAc and MTES was stirred under an ethanol solvent of a molar ratio of MTES/ metal alkoxide $=1 / 0.05$, MTES $/$ ethanol $=1 / 3$, and MTES $/$ $\mathrm{H}_{2} \mathrm{O}=1 / 2$, respectively. As a catalyst for the hydrolysis and condensation of silicon alkoxide, $1 \mathrm{~N}-\mathrm{HCl}$ was added to the above mixtures in a ratio MTES/ $\mathrm{HCl}=1 / 0.005$. In the case of $\mathrm{Al}\left(\mathrm{O}\left(\mathrm{CH}_{3}\right) \mathrm{CHC}_{2} \mathrm{H}_{5}\right)_{3}$, 2-butanol with a molar ratio of alkoxide $/ 2$-butanol $=1 / 20$ was used as the solvent instead of ethanol. Hereafter, the hybrid coating films were referred as Ta-, Ti-, Al-PMSQ, and pure PMSQ, respectively, according to the doped metal alkoxide. Next, the coating films on the SUS $420 \mathrm{~J} 2$ substrate were prepared by dip-coating in the above sol solution (after mixing for $1 \mathrm{~h}$ ). These substrates were immersed into the solvent solution, then pulled up at a rate of approximately $5 \mathrm{~mm} / \mathrm{s}$ and cured at $40^{\circ} \mathrm{C}$ and $80^{\circ} \mathrm{C}$ for $48 \mathrm{~h}$ and at $200^{\circ} \mathrm{C}$ for $72 \mathrm{~h}$. After curing, the various PMSQ based coating films were heated to $400^{\circ} \mathrm{C}$ under an Ar flow.

The surface roughness of the coating films was measured by arithmetic average roughness $\left(R_{\mathrm{a}} ; \mu \mathrm{m}\right.$, JIS B 0601) with Mitsutoyo SURFPAC. As a rough mechanical characterization of the coating film, the indentation test of $\mathrm{Si}_{3} \mathrm{~N}_{4}$ sphere with a diameter of $1.56 \mathrm{~mm}$ was carried out for the coating film and the load of $300 \mathrm{~N}$ was applied after $0.8 \mathrm{ml}$ of oil was dropped on the coating films. The oil used was $10 \mathrm{~W}-30$ engine oil (Nippon Oil Corporation, Tokyo).

The sliding property of the coating film was evaluated by pin-on-disk experiments (Kyowa Giken, Tokyo) against an FCD pin with a diameter of $36 \mathrm{~mm}$. Before the sliding tests, $0.8 \mathrm{ml}$ of oil was dropped on the coating film. The sliding velocity was in the range of $0.5-0.0042 \mathrm{~m} / \mathrm{s}$ and the load was 


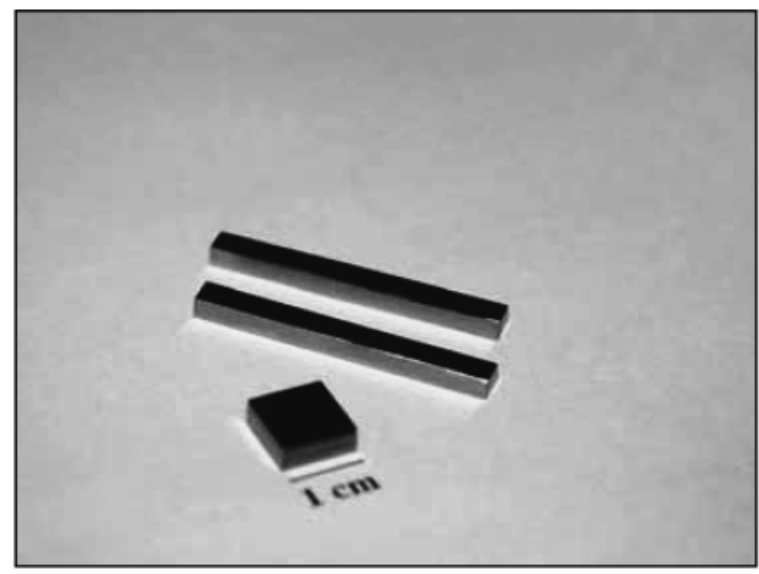

Fig. 1. Photographs of the Ta-PMSQ hybrid coating film on the SUS substrate.

9.8 N. The sliding test was run for $10 \mathrm{~min}$ at various measuring points.

\section{Results and discussion}

Figure 1 shows photographs of the Ta-PMSQ coating films on the SUS substrates. After drying, the obtained coating films appeared transparent and crack-free. In addition, a simple characterization based on JIS K5400 showed the maximum adhesion in a cross-cut tape test and a $9 \mathrm{H}$ value in a pencil scratch hardness examination.

Figure 2 shows the contact angle for the oil and the surface roughness $\left(R_{\mathrm{a}} ; \mu \mathrm{m}\right)$ of coating films. For reference, the SUS substrate was also described. The results showed that the contact angle decreased in the order of pure PMSQ $>$ Ta-PMSQ $>\mathrm{Al}-\mathrm{PMSQ} \approx \mathrm{Ti}-\mathrm{PMSQ}$ hybrid coating films. The surface roughness showed an order of Al-PMSQ $>$ Ti- PMSQ $>$ TaPMSQ $>$ pure PMSQ. Materials with rough surfaces generally show a larger surface area and also provide a larger adsorption site, which result in the greater spread of oil. The roughness results almost correspond to the order of wettability. The lowest contact angle of the SUS substrate is due to the components of the oil, as the oil is manufactured to provide a chemical affinity for SUS.

Figure 3 shows typical FE-SEM micrographs of the indented surface of (A) PMSQ and (B) Ta-PMSQ coating films. These results roughly suggest the mechanical properties of the coating film. The PMSQ coating films showed many cracks in the indented surface, compared to the Ta-PMSQ coating film. These cracks are considered to come from the formed coating film itself by the indentation and/or the formed crack by peeling from plastic-deformed substrate. As seen from previous reports, the fracture behavior of the PMSQ-based hybrid is found to be strongly correlated with its molecular structure, namely, the ratio of the $T^{3}$ unit. $^{2)}$ In the PMSQ hybrid material, the high ratio of the $T^{3}$ unit means the occurrence of condensation among silanol $(\equiv \mathrm{Si}-\mathrm{OH})$, less terminal sites such as silanol or ethoxy $\left(\equiv \mathrm{Si}-\mathrm{OC}_{2} \mathrm{H}_{5}\right)$ group, and the following larger number of inorganic siloxane bonds, compared with the $T^{1}$ and $T^{2}$ units. Thus, strength and elastic modulus increase with the increase of the ratio of the $T^{3}$ unit. $^{2), 8)}$ In contrast, the hybrid with a high ratio of $T^{1}$ and $T^{2}$ units can show the flexibility and the larger elongation at fracture. In our previous report, the ratio of $T^{3}$ unit was pure PMSQ $>$ TaPMSQ hybrid. ${ }^{1)}$ Based on the cross cut tape test, the adhesion between the coating film and the substrate showed a similar

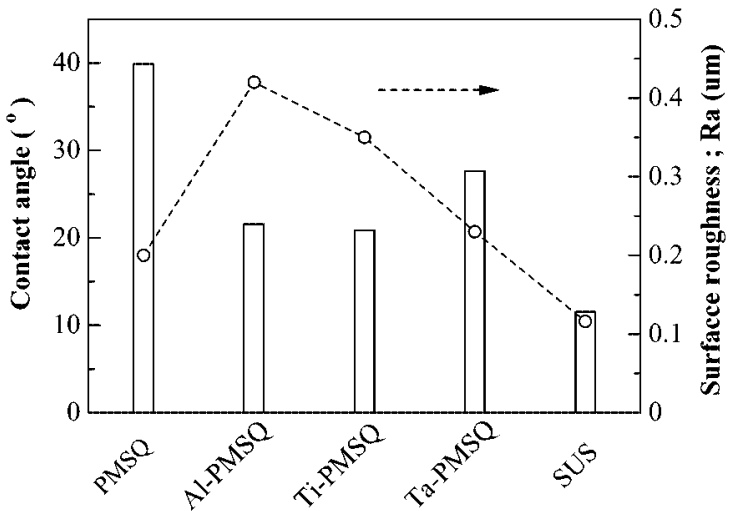

Fig. 2. Contact angle of obtained coating films for engine oil and their surface roughness.

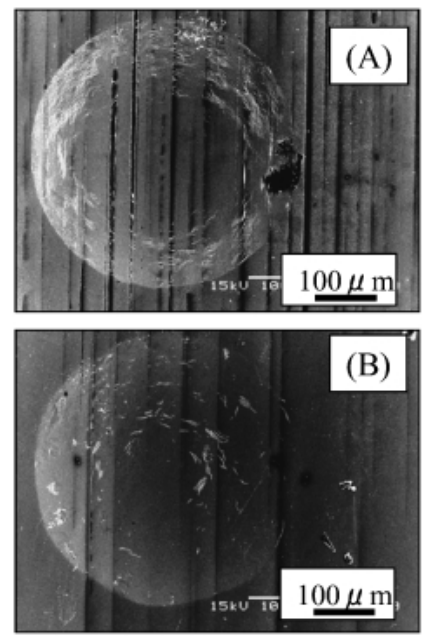

PMSQ

Fig. 3. FE-SEM micrographs of the indented surface of (A) PMSQ and (B) Ta-PMSQ coating films.

maximum value for both coating films. Thus, the result of indentation reflects that the pure PMSQ coating film with a high ratio of $T^{3}$ unit is more brittle compared with the TaPMSQ coating film.

Figure 4 shows the friction coefficient of various hybrid coating films against the FCD pin with changing sliding velocities. As a reference, the results for the SUS plate, which was used as the base material for the coating film, is also presented. As can be seen from the results, the friction coefficient of the coating films in the velocity of $0.4 \mathrm{~m} / \mathrm{s}$ corresponded to the order of oil wettability, which suggests the hydrodynamic lubrication, namely, the maintaining of the lubricating oil film between coating film and pin. Then, the friction coefficient gradually increased with the decreasing sliding velocity. When the sliding velocity reached around $0.1 \mathrm{~m} / \mathrm{s}$, the Ti-PMSQ and PMSQ coating films showed lower friction coefficients than the SUS. Under sliding conditions below a velocity of $0.1 \mathrm{~m} / \mathrm{s}$, the friction coefficient of the Ti-PMSQ coating film was lower than that of Al-PMSQ, though the Al- and Ti-PMSQ coating films showed similar wettability. This indicates that a lubricating oil film on the Ti-PMSQ coating film was maintained between the coating film and the oil. It may be difficult to maintain the lubricating oil film on the Al-PMSQ coating film. This maintaining comes from the interaction between 


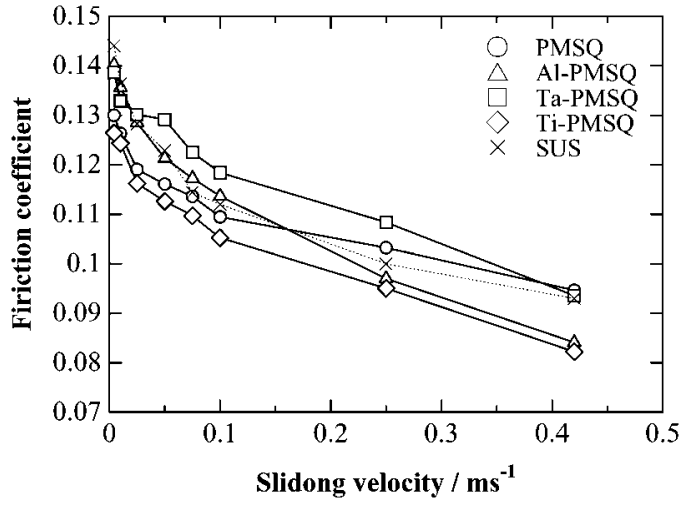

Fig. 4. Friction coefficients of coating films with the changing sliding velocity.

oil and coating film. Under lower sliding velocity, in other words, in the region of mixed or boundary lubrication, the solid-solid contact (between coating film and pin), which increases the friction coefficient, can partially occur. However, the maintenance of the lubricating oil film on the coating film may possibly decrease solid-solid contact. As a result, the lower friction coefficient of the Ti-PMSQ coating film is observed.

As mentioned above, under higher sliding velocity, the Aland Ti-PMSQ coating films showed lower friction coefficients due to the higher wettability of the oil. On the other hand, under lower sliding velocities, the friction coefficient of the pure PMSQ and Ti-PMSQ hybrid coating films was lower than that of Al-PMSQ coating film or SUS. This may reflect the maintaining of the lubricating oil film.

\section{Conclusion}

In this work, the wettability of oil and the sliding properties of metal-containing polymethylsilsesquioxane (PMSQ) hybrid coating films were assessed. The wettability of a coating film for oil was improved by the presence of a metal component, in the order of $\mathrm{Al}->\mathrm{Ti}->\mathrm{Ta}->$ PMSQ coating films. The results for the friction coefficient showed that the TiPMSQ coating film had a lower value than that of other films and SUS substrate, which was due to its high wettability and the maintenance of the lubricating oil film on the coating films.

\section{References}

1) Fukushima, M., Yasuda, E., Nakamura, Y., Kita, H., Kawabata, H. and Tanabe, Y., J. Ceram. Soc. Japan, Vol. 113, pp. 210-215 (2005).

2) Takamura, N., Gunji, T., Hatano, T. and Abe, Y., J. Polym. Sci. A: Polym. Chem., Vol. 37, pp. 1017-1026 (1999).

3) Makita, H., Akamatsu, Y., Yamazaki, S., Kai, Y. and Abe, Y., J. Ceram. Soc. Japan, Vol. 105, pp. 1012-1017 (1997).

4) Katayama, S., Yoshinaga, I., Kubo, Y. and Yamada, N., J. Ceram. Soc. Japan, Vol. 111, pp. 743-748 (2003).

5) Katayama, S., Yamada, N., Shibata, Y., Sakai, T. and Satake, S., J. Ceram. Soc. Japan, Vol. 110, pp. 549-553 (2003).

6) Kita, H., Hirai, T., Iizuka, T. and Osumi, K., J. Ceram. Soc. Japan, Vol. 111, pp. 692-697 (2003).

7) Kita, H., Hirai, T., Iizuka, T. and Osumi, K., J. Ceram. Soc. Japan, Vol. 111, pp. 581-586 (2003).

8) Abe, Y., Kagayama, K., Takamura, N., Gunji, T., Yoshihara, T. and Takahashi, N., J. Non-Cryst. Solids, Vol. 261, pp. 39-51 (2000). 